\title{
KSZTAŁTOWANIE POSTAWY SPOŁECZNEJ ŚWIADOMEGO KONSUMENTA PALIW I ENERGII JAKO CEL W ZARZĄDZANIU PROEKOLOGICZNYMI ORGANIZACJAMI TRZECIEGO SEKTORA
}

\author{
Anna Mielczarek \\ Politechnika Częstochowska \\ Wydział Zarządzania
}

\begin{abstract}
Streszczenie: Celem artykułu jest ukazanie potrzeby edukacji ekologicznej, prowadzonej przez instytucje inne niż państwowe i samorządowe wywodzące się i będące z reguły organicznymi częściami społeczeństwa obywatelskiego. W artykule sprecyzowano także pojęcie organizacji trzeciego sektora i ukazano ich rolę w kształtowaniu świadomej, proekologicznej postawy społecznej. Podjęto się również rozważenia problematyki konieczności współpracy pomiędzy wszystkimi trzema sektorami i ich istotnej roli w zrównoważonym rozwoju.
\end{abstract}

Słowa kluczowe: alarm smogowy, CSR, edukacja ekologiczna non profit, NGO, trzeci sektor, ruch społeczny, smog, trwały rozwój, zrównoważony rozwó

DOI: 10.17512 /znpcz.2018.1.16

\section{Społeczeństwo obywatelskie w Polsce i trzeci sektor}

Po raz pierwszy w nowożytnej Europie, koncepcja społeczeństwa obywatelskiego pojawiła się w XVII i XVIII wieku. Wówczas to, w okresie renesansu w Anglii, narodził się nurt angielskiej myśli społecznej, który nawiązywał do stwierdzeń Arystotelesa (Arystoteles 2002, s. 5 i dalsze), dla którego najwyższym wyrazem istnienia społeczeństwa obywatelskiego było utworzenie państwa.

Ze względu na burzliwą historię kontynentu i niedemokratyczne rządy koncepcja ta była niszowa. Jeszcze w połowie XV wieku merkantyliści postrzegali trzysektorową strukturę gospodarki w zupełnie odmienny sposób, nie mający nic wspólnego ze współczesnym rozumieniem problematyki w kontekście społecznym. Zgodnie z koncepcją Fishera ${ }^{1}$, sformułowaną w latach 30 . XX wieku, istnieją trzy sektory gospodarki:

- pierwszy sektor to dziedziny wytwarzające żywność i surowce, wśród których najważniejszą rolę odgrywają rolnictwo i przemysł wydobywczy;

- drugi sektor to rodzaje produkcji przemysłowej (przetwórstwa);

- trzeci sektor to pozostałe dziedziny działalności gospodarczej zajmujące się świadczeniem usług: handel, transport, gastronomia, usługi osobiste, nauka, sztuka, ochrona zdrowia, ubezpieczenia i wychowanie (Kwiatkowski 1982, s. 13-14).

\footnotetext{
${ }^{1}$ Irving Fisher (1867-1947) - amerykański ekonomista, przedstawiciel szkoły neoklasycznej w ekonomii.
} 
Prawdziwy renesans idei społeczeństwa obywatelskiego w Europie nastąpił w latach 80. XX wieku, w okresie odrodzenia i kształtowania się nowoczesnej myśli neoliberalnej wraz ze zmianami zapoczątkowanymi w sierpniu $1980 \mathrm{roku}$ w Polsce, a później w całym regionie Europy Środkowej i Wschodniej. Śmiało można stwierdzić, że zmiany społeczne i polityczne rozpoczęły się, kiedy złamano monopol państwa na tworzenie związków zawodowych i zarejestrowano Niezależny Samorządny Związek Zawodowy „Solidarność” (Barański b.r., s. 8). Ten fakt stanowił początek procesu, który zaowocował tworzeniem innych związków zawodowych. Po 13 grudnia 1981 r. proces tworzenia tego typu organizacji osłab1 znacząco w społeczeństwie, aby przybrać na sile po roku 1989.

W latach 90. w Polsce wynikiem zmian ustrojowych były także procesy, które zapoczątkowały nowy porządek społeczno-ekonomiczny. Bardzo poważne zmiany spowodowane odchodzeniem od gospodarki centralnie planowanej do gospodarki rynkowej oraz procesy prowadzące do demokratyzacji państwa spowodowały pojawienie się luki w przestrzeni społeczno-gospodarczej. Luka, która dotychczas wypełniana była przez państwo, dała szansę zaistnienia dla nowego typu organizacji.

W tym czasie zmieniła się całkowicie koncepcja funkcjonowania państwa w sferze ustrojowej, jak i społeczno-ekonomicznej. Nie można ukrywać, że stan państwa z początku lat 90 . był zagrożeniem dla systemu polityki społecznej. Transformacja gospodarcza Polski spowodowała również, że priorytetem funkcjonowania przedsiębiorstw - zgodnie z doktryną kapitalistyczną - stała się realizacja zysku, czego konsekwencją była rezygnacja $\mathrm{z}$ wielu pełnionych dotychczas funkcji socjalnych w stosunku do zatrudnionych pracowników. W tych warunkach powstało miejsce dla funkcjonowania sektora pozarządowego, stanowiącego pomost pomiędzy strukturami państwa, społeczeństwem, a sektorem prywatnym (Tyrakowski 2007).

Dynamicznie zaczęła wzrastać liczba różnego rodzaju fundacji, stowarzyszeń i związków, co spowodowało powstanie nowej terminologii. Do czasu transformacji ustrojowej istniało już określenie „organizacja społeczna”, ale z czasem i dla podkreślenia odrębności tych organizacji zaczęto używać określeń: „organizacje pozarządowe”, „organizacje non profit” i „organizacje trzeciego sektora”. Nazwy do dziś używane jasno akcentują niezależność tych organizacji od instytucji i struktur państwowych oraz całkowity brak nastawienia na zysk ${ }^{2}$. W konsekwencji, obok instytucji państwowych - administracji publicznej, która jest pierwszym sektorem, i podmiotów nastawionych na zysk, czyli szeroko rozumianego biznesu i prywatnej przedsiębiorczości, czyli drugiego sektora - pojawił się twór całkowicie nowy. Jego inność polegała na tym, że nie wpisywał się i nie stanowił w żaden sposób elementu struktury państwa ani nie był nastawiony na zysk - stąd nazwa „organizacje trzeciego sektora".

Niestety organizacje pozarządowe, przez sceptyków często postrzegane są jako konsumenci środków publicznych lub organizacje dążące do realizacji interesów wąskich grup społecznych. Nie można wykluczyć, że i takie sytuacje mają miejsce, jednak nadzór publiczny nad organizacjami trzeciego sektora znacznie niweluje tego typu nadużycia. Dodatkowo organizacje NGO często stają w opozycji do in-

${ }^{2}$ Non profit oznacza: nie dla zysku, nie przynoszący dochodu (http://sjp.pl/non+profit). 
stytucji państwowych, co powoduje konflikty na linii organizacje pozarządowe administracja państwowa, jednak takie rozdźwięki są istotą ustroju demokratycznego. Sektor NGO dynamicznie się rozrasta, wynika to z dużego napływu zapotrzebowań społecznych, ze strony różnych grup, na przykład bezrobotnych, oraz spadku zaufania do instytucji publicznych. Przy tym wszystkim pamiętać należy, że podstawową cechą odróżniającą ten sektor od sektora prywatnego i publicznego jest wykorzystanie wszelkich zysków z prowadzonej działalności do realizacji celów statutowych. W najbliższych latach można się spodziewać, że polityka społeczna nie będzie efektywna bez wykorzystania potencjału organizacji społecznych przez sektor publiczny. Szybkie tempo starzenia się populacji wywoła znaczny przyrost potrzeb opiekuńczych (Wydział Spraw Społecznych Urzędu Miasta Gorzowa Wlkp. 2015).

W latach 70. w społeczeństwach rozwiniętych organizacje tego typu odgrywały już dużą rolę, będąc swego rodzaju odpowiedzią na niedoskonałość klasycznych systemów gospodarczych, które często pomijały obywateli i nie dostrzegały ważnych problemów społecznych.

\section{Specyfika zarządzania w organizacjach pozarządowych}

W latach 70. XX wieku w organizacjach drugiego sektora, czyli biznesowych, rozwijała się koncepcja planowania i zarządzania strategicznego. W sposób spontaniczny i naturalny koncepcja ta zaczęła również przenikać do organizacji typu non profit. Ze względu na specyfikę organizacji model zarządzania jest tu zdecydowanie inny niż $w$ instytucjach biznesowych, ponieważ zmiany w środowisku zewnętrznym na bieżąco determinują wewnętrzne działania NGO. Jednak by prężnie działać, każda organizacja musi budować trzy rodzaje współzależnych od siebie kapitałów. Te kapitały to: kapitał ludzki - zespół osób, zaangażowanych w działalność organizacji z pożądaną wiedzą i umiejętnościami, kapitał społeczny - sieć kontaktów międzyludzkich, łączących ludzi i instytucje, opierająca się na zaufaniu, wspólnych wartościach i gotowości do wymiany informacji, oraz kapitał materialny - pieniądze, lokal, sprzęt, możliwość uzyskania rabatów. W rozwoju NGO jest jednak jedna podstawowa zasada: im silniejszy kapitał ludzki i społeczny, tym silniejszy kapitał materialny.

Organizacje pozarządowe działają pod presją ciągłej kontroli społecznej i opinii publicznej. Specyfika procesów zarządzania w organizacjach pozarządowych wynika z tego, że najważniejsze dla nich są zasoby niematerialne, a główną umiejętnością jest realizacja misji (Domański 2010, s. 176). W obecnych czasach jednak zarządzający NGO muszą dostosować się do wymagań i oczekiwań społecznych. $\mathrm{W}$ tym kontekście marketing $\mathrm{w}$ organizacjach non profit dotyczy ułatwienia procesu wymiany między organizacją a odbiorcami jej usług tak, by zaspokoić potrzeby społeczne. Główne cele NGO są odmienne od celów wyznaczanych w organizacjach nastawionych na zysk. Działalność tych organizacji jest powiązana bezpośrednio z bardzo szerokim wachlarzem potrzeb społecznych, co powoduje ich różnorodność, jak choćby zmianę postawy społecznej. 


\section{Organizacje ekologiczne działające w Polsce}

$\mathrm{Na}$ świecie istnieją różne typologie organizacji non profit, w zależności od tego, w jaką działalność się angażują. Według międzynarodowego systemu ICNPO ${ }^{3}$ organizacje propagujące ochronę środowiska znajdują się $\mathrm{w}$ grupie V. Obecnie w Polsce funkcjonuje około 1000 organizacji proekologicznych, zarówno takich, które tradycją sięgają do okresu przedwojennego, jak i stosunkowo młodych, powstałych w latach 80. i 90. XX wieku (Kowałczewska b.r.). Na terenie naszego kraju działa także szereg organizacji międzynarodowych, które są symbolem starań o ochronę przyrody i wszelkich działań proekologicznych.

Aby móc w pełni rozpatrzyć kwestię starań organizacji w dziedzinie edukacji i propagowania zachowań proekologicznych, przedstawię poniżej najważniejsze z nich i wskażę ich najistotniejsze działania:

- Liga Ochrony Przyrody - organizacja ekologiczna powstała w Polsce w 1927 roku. Głównym założeniem jej twórców była chęć uwrażliwiania człowieka, a szczególnie młodzieży, na przyrodę, budzenie jej umiłowania, szerzenie zrozumienia istoty, znaczenia i celów. LOP zabiega o zapewnienie bezpieczeństwa ekologicznego współczesnemu i przyszłym pokoleniom. Działa przez organizowanie seminariów, warsztatów, konferencji, obozów, koloni, wycieczek przyrodniczych, konkursów, wystaw i olimpiad. Podejmuje również działania o charakterze interwencyjnym. LOP współpracuje z licznymi krajowymi i międzynarodowymi organizacjami ekologicznymi, jak Międzynarodowa Koalicja „Wolontariusze Przyrody” (CVA), Młodzież i Środowisko Europy (YEE), Europa Nostra oraz Światowe Towarzystwo Ochrony Zwierząt (WSPA). Jest m.in. członkiem założycielem Światowej Unii Ochrony Przyrody (IUCN). Liga Ochrony Przyrody prowadzi również Europejskie Centrum Ekologiczne, które jest inicjatorem i realizatorem Europejskiej Zielonej Karty (European Green Card), która spotkała się ze znacznym zainteresowaniem instytucji krajowych i międzynarodowych.

- Centrum Prawa Ekologicznego z siedzibą we Wrocławiu (członek European Environmental Bureau z siedzibą w Brukseli) - niezależny ośrodek badań i doradztwa specjalizujący się w prawie ochrony środowiska. Od 1999 roku prowadzi działalność opiniodawczo-doradczą w zakresie prac legislacyjnych.

- Fundacja Nasza Ziemia od 1994 roku specjalizuje się w edukacji ekologicznej i obywatelskiej. Działa na rzecz podnoszenia poziomu świadomości ekologicznej społeczeństwa. Główne obszary jej działania to zarządzanie zasobami i gospodarka odpadami, poszanowanie energii, wody, ziemi i powietrza, poszanowanie krajobrazu przyrodniczo-kulturowego oraz wspieranie partnerstw i CSR ${ }^{4}$. Fundacja Nasza Ziemia jest organizatorem akcji „Sprzątanie świata - Polska”.

- Fundacja Wspierania Inicjatyw Ekologicznych powstała w 1989 roku w Krakowie. Jej misją jest wspieranie działań sprzyjających poprawie stanu środowi-

${ }^{3}$ ICNPO - International Classification of Non Profit Organizations.

${ }^{4} \mathrm{Z}$ ang. CSR (Corporate Social Responsibility) społeczna odpowiedzialność biznesu - koncepcja, według której przedsiębiorstwa na etapie budowania strategii uwzględniają interesy społeczne i ochronę środowiska, a także relacje z różnymi grupami interesariuszy. 
ska naturalnego podejmowanych przez organizacje pozarządowe, samorządy lokalne, instytucje, a także zwykłych obywateli. Działalność Fundacji Wspierania Inicjatyw Ekologicznych dotowana była ze środków Narodowego Funduszu Ochrony Srodowiska i Gospodarki Wodnej.

- Fundacja WWF (World Wildlife Fund (https://www.worldwildlife.org/)) - organizacja ekologiczna powstała w 1961 roku z inicjatywy generalnego dyrektora UNESCO Juliana Huxleya. Narodowe oddziały WWF funkcjonują w wielu krajach, główna siedziba znajduje się w Szwajcarii. WWF zainicjował, przeprowadził lub pomógł w realizacji ponad 12600 przedsięwzięć na rzecz ochrony przyrody w 154 krajach świata, przyczyniając się do powstania 270 parków narodowych. WWF w latach 80. współtworzył Światową Strategię w Zakresie Ochrony Przyrody, która opublikowana jednocześnie w 34 stolicach świata stała się podstawą kompleksowego spojrzenia na ochronę środowiska oraz zrównoważone wykorzystanie zasobów naturalnych naszej planety.

- Greenpeace - międzynarodowa organizacja ekologiczna działająca od 1971 roku na rzecz ochrony środowiska naturalnego. Koncentruje się na najbardziej istotnych, globalnych zagrożeniach dla bioróżnorodności i środowiska, a celem kampanii prowadzonych przez Greenpeace jest zwrócenie uwagi opinii publicznej na sześć głównych problemów dotyczących: obszarów ochrony środowiska - ochrony lasów i lasów deszczowych, ochrony oceanów i mórz, ochrony przed substancjami toksycznymi, globalnego ocieplenia i zmian klimatycznych, energii oraz organizmów modyfikowanych genetycznie. Biura Greenpeace znajdują się w ponad czterdziestu krajach świata. Aby zachować swoją niezależność, Greenpeace nie przyjmuje dotacji od rządów, partii politycznych i korporacji. Działania Greenpeace finansowane są dzięki wsparciu indywidualnych darczyńców.

- Klub Gaja - organizacja ekologiczna zajmująca się ochroną środowiska naturalnego i prawami zwierząt w Polsce, działa od 1989 roku, organizując akcje w obronie przyrody i zwierząt. Do bardziej znanych należą: Ogólnopolska Kampania „Teraz Wisła”, mająca chronić naturalny stan największej polskiej rzeki, i Ogólnopolska Kampania „Zwierzę nie jest rzeczą”. Gaja współpracuje z trzema tysiącami placówek w całym kraju. Programy edukacji ekologicznej Klubu Gaja opierają się na aktywności lokalnej, w szczególności dzieci i młodzieży przy udziale przedstawicieli różnych instytucji, samorządów, administracji publicznej, organizacji pozarządowych i biznesu.

- Polski Klub Ekologiczny - stowarzyszenie o zasięgu ogólnopolskim. Istnieje od 1984 roku. Jest pierwszą organizacją w Polsce sprzeciwiającą się polityce traktowania środowiska jako „dobra niczyjego”. Zarząd Główny Polskiego Klubu Ekologicznego znajduje się w Krakowie. Celem działań PKE jest realizacja idei ekorozwoju, powszechna edukacja ekologiczna, dbałość o zachowanie równowagi między rozwojem cywilizacji technicznej a wartościami humanistycznymi.

- Ośrodek Działań Ekologicznych „Źródła” - organizacja ekologiczna od 15 lat zajmuje się szeroko rozumianą edukacją ekologiczną, przyrodniczą i obywatel- 
ską, poprzez organizowanie warsztatów dla młodzieży, zielonych szkół, szkoleń, wystaw, projektów informacyjnych.

- Stowarzyszenie Centrum Europejskie Zrównoważonego Rozwoju (CEZR) organizacja ekologiczna z siedzibą główną we Wrocławiu istnieje od 2002 roku, zrzeszając osoby związane zawodowo z integracją europejską, ochroną środowiska, działaniami na rzecz rynku pracy i rozwoju organizacji pozarządowych. CEZR jest ośrodkiem szkoleniowo-doradczym prowadzącym działalność w zakresie m.in. wspierania organizacji pozarządowych, rozwoju odnawialnych źródeł energii, działalności eko i agroturystycznej, wdrażania zasad zrównoważonego rozwoju, polityki regionalnej i funduszy strukturalnych UE.

- Towarzystwo na rzecz Ziemi - organizacja ekologiczna działającą na rzecz zachowania, ochraniania i odtwarzania dziedzictwa przyrodniczego oraz ochrony zdrowia i życia ludzi przed szkodliwym oddziaływaniem zanieczyszczeń. Istnieje od 1989 roku i od roku 1997 prowadzi działania na terenie całego kraju. Stowarzyszenie działa również na rzecz tworzenia warunków dla rozwoju demokracji lokalnej, umocnienia pokoju oraz upodmiotowienia społeczeństwa.

\section{Międzynarodowa Unia Ochrony Przyrody i Jej Zasobów}

Przedstawione powyżej organizacje to zaledwie część ze wszystkich działających na rzecz ochrony środowiska. Są one jednak na tyle znaczące i ważne, że należy zasygnalizować ich istnienie. IUCN, o której wspomniano już podczas prezentacji LOP, to największa światowa organizacja ekspercka. IUCN została założona w 1984 roku jako pierwsza światowa organizacja skoncentrowana na problemach środowiska naturalnego. Skupia: 200 agencji rządowych, 900 organizacji pozarządowych i instytucji naukowych, 83 państwa jako ,state members”. W ramach organizacji pracuje 6 komisji tematycznych zrzeszających 11000 ekspertów ze 160 krajów, 1000 pracowników jest członkiem obserwatorem ONZ. Podejmuje działania na rzecz zrównoważonego rozwoju, działając pod mottem: „Sprawiedliwy świat ceniący i zachowujący trwale przyrodę". IUCN jako eksperckie ciało doradcze współpracuje OECD, Bankiem Światowym, Unią Europejską m.in. w dziedzinie spójności i integracji polityk gospodarki przestrzennej, rolnictwa, leśnictwa, turystyki i zrównoważonego biznesu. Organizacja podjęła inicjatywę ochrony klimatu i popularyzuje integracje działań prowadzących do ograniczania emisji $\mathrm{CO}_{2}$ dzięki zwiększaniu lesistości. IUCN, wspierając Konwencję o różnorodności biologicznej, wiąże całość zasobów żywych Ziemi z życiem człowieka. Jakość życia ludzkości zależy od tego, co zapewnia jej żywe bogactwo planety. Wiąże się to z zasadą zrównoważonego rozwoju: ochrona i umiarkowane korzystanie $\mathrm{z}$ bioróżnorodności zapewnia jej trwałość i utrzymanie sieci życia dla przyszłych pokoleń. 


\section{Potrzeba edukacji ekologicznej w Polsce przy integracji wszystkich trzech sektorów}

Celem edukacji ekologicznej prowadzonej przez instytucje i organizacje NGO jest uświadamianie Polakom, że jakość życia zależy od stanu środowiska, w którym funkcjonują. Planowanie edukacji ekologicznej należałoby zacząć od diagnozy, która wskaże kierunek działań. Świadomość ekologiczna mieszkańców naszego kraju znacznie zwiększyła się $\mathrm{w}$ momencie wejścia $\mathrm{w}$ życie ustawy o utrzymaniu czystości w gminach (Ustawa z dnia 13 września 1996 r. ...). W związku z tym główne pozytywne zmiany odnotowuje się w obszarze gospodarowania odpadami. Śmieci zdecydowanie rzadziej postrzegane są jako istotny problem środowiska naturalnego w Polsce. Coraz więcej gospodarstw segreguje odpady. Poczucie indywidualnego wpływu na stan środowiska jest stosunkowo wysokie, jednak jeszcze dość niskie w porównaniu ze świadomością przeciętnego Europejczyka. W codziennym życiu ograniczamy się do tak naprawdę elementarnych zasad w zakresie ochrony środowiska. Zgodnie z badaniami CBOS jedynymi działaniami ekologicznymi, jakie w ostatnim roku podjęła większość respondentów, były starania o ograniczenie zużycia energii elektrycznej i wody oraz unikanie kupowania produktów szkodliwych dla środowiska (CBOS 2000).

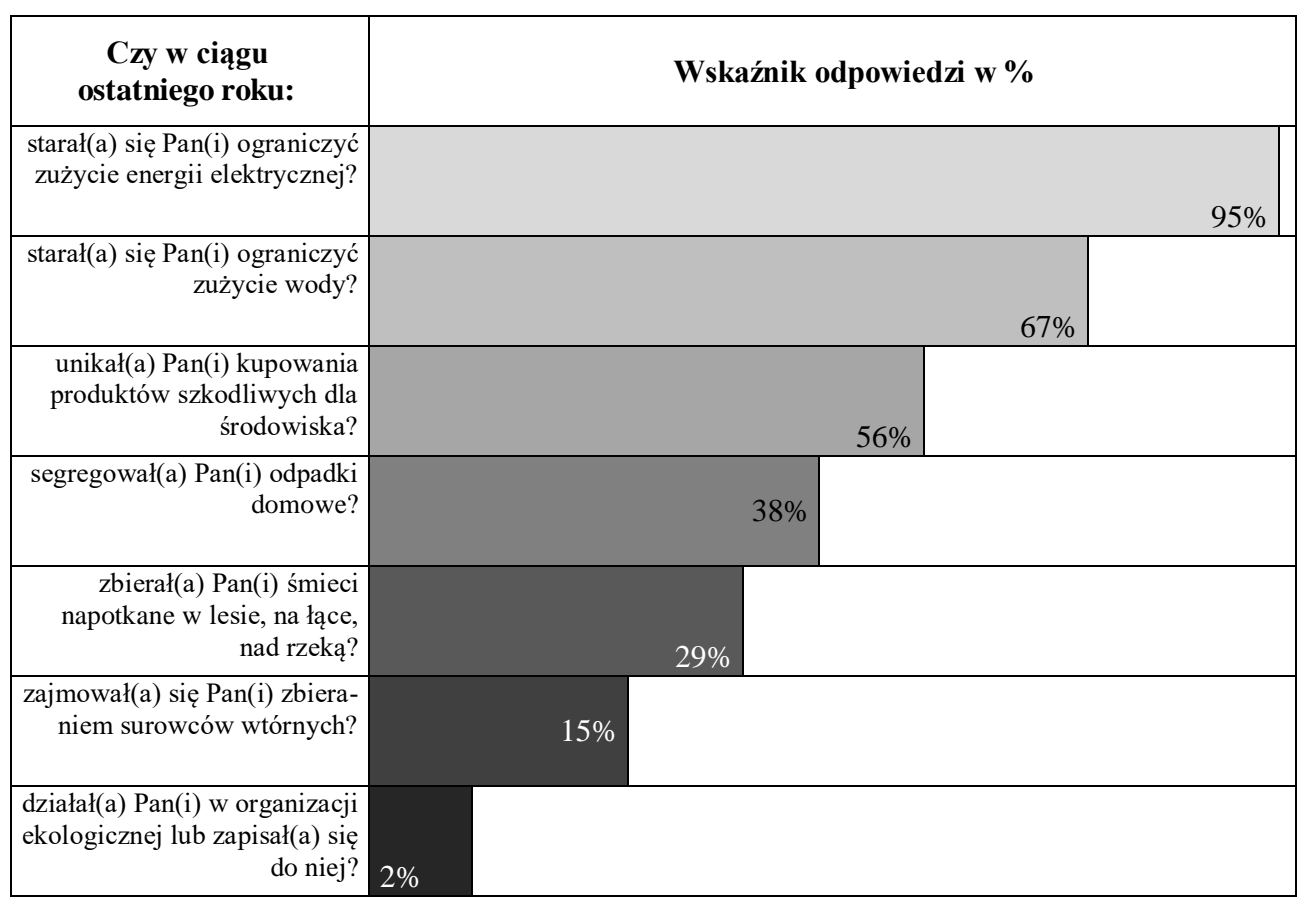

Źródło: Opracowanie własne 
Zasada zrównoważonego rozwoju wpisana jest w Konstytucję Rzeczypospolitej Polskiej ${ }^{5}$ oraz zapisana traktatach Unii Europejskiej. Jego istotą jest powiązanie szybkiego rozwoju gospodarczego i wzrostu jakości życia ludności z poprawą stanu środowiska przyrodniczego. Można jej sprostać tylko dzięki zintegrowaniu polityk: środowiskowej, społecznej i gospodarczej. Tu właśnie jest pole do popisu dla organizacji pozarządowych. To właśnie organizacje NGO, w przeciwieństwie do instytucji pierwszego sektora, mają szersze pole manewru, nie są ograniczone $K o$ deksem postepowania administracyjnego oraz innymi ustawami, które nie pozwalają, a raczej opóźniają spontaniczne reakcje i działania osób odpowiedzialnych za edukację ekologiczną. Organizacje trzeciego sektora, będące „głosem społeczeństwa", powinny być elementem łączącym i integrującym wokół siebie i swoich działań pierwszy i drugi sektor.

Mimo że Polacy z roku na rok coraz lepiej oceniają dbanie o środowisko w Polsce, to wielu z nich wciąż nie do końca zdaje sobie sprawę, jakie działania należy podejmować, by stać się częścią społeczności mądrze korzystającej z paliw i energii. Istotne jest, że osoby, które samodzielnie podejmują działania ekologiczne, są bardziej przekonane o własnej sprawczości i z większym optymizmem patrzą na stan środowiska w przyszłości. Aż 75\% Polaków uważa, że ochrona środowiska może pozytywnie wpłynąć na rozwój gospodarczy (TNS 2015). Polacy zadowalają się tym, co usłyszą w telewizji - właśnie to medium jest podstawowym źródłem wiedzy o sprawach środowiska naturalnego. Tym bardziej należy nasilać pozaszkolne działania edukacyjne.

Budowanie świadomości ekologicznej poprzez edukację trzeba zacząć w jak najmłodszych grupach wiekowych. Początkowo należy edukować przez zabawę, np.: w przedszkolach. I tu doskonałym przykładem jest projekt „Kubusiowi ${ }^{6}$ Przyjaciele Natury", realizowany przez Fundację Maspex. W akcji wzięło już udział ponad 2,5 miliona dzieci i jest ona przykładem symbiotycznego działania organizacji drugiego i trzeciego sektora. Firma Maspex, zbieżność nazw organizacji jest zamierzona, szczyci się działalnością społeczną i wysokim poziomem świadomości ekologicznej i odpowiedzialności społecznej. W zakładach Grupy Maspex funkcjonują nowoczesne kotłownie gazowe, dzięki którym firma zmniejszyła emisję do atmosfery tlenków siarki, azotu, węgla i dwutlenku węgla przez wykorzystanie biogazów wytwarzanych przez oczyszczalnie firmy. Maspex uruchomił również instalacje do kogeneracji i poligeneracji, czyli technologii polegającej na jednoczesnym wytworzeniu energii elektrycznej i cieplnej. W zakładzie produkcyjnym w Tymbarku powstała farma fotowoltaiczna, dzięki której możliwa jest konwersja energii promieniowania słonecznego na energię elektryczną, a zakład produkcyjny w Olsztynku posiada pozwolenie zintegrowane nakładające na firmę obowiązek sto-

\footnotetext{
5 „Rzeczpospolita Polska strzeże niepodległości i nienaruszalności swojego terytorium, zapewnia wolności i prawa człowieka i obywatela oraz bezpieczeństwo obywateli, strzeże dziedzictwa narodowego oraz zapewnia ochronę środowiska, kierując się zasadą zrównoważonego rozwoju" (Konstytucja Rzeczypospolitej Polskiej z dnia 2 kwietnia 1997 r. ..., art. 5).

${ }^{6}$ Nazwa i sylwetka Kubusia została zaczerpnięta od nazwy popularnego soku dla dzieci.
} 
sowania najlepszych dostępnych technik ${ }^{7}$ (ang. BAT - Best Available Technique) dla branży spożywczej. Ma on na celu ogólne ograniczenie emisji i oddziaływania na środowisko naturalne.

W 2008 roku powstała baza partnerstwa na rzecz zrównoważonego rozwoju. Partnerstwo takie opiera się na dobrowolnej deklaracji przystąpienia osoby fizycznej lub prawnej do partnerstwa, co samo w sobie nie rodzi skutków prawnych ani finansowych. Partnerstwo bazuje na dobrowolności udziału członków w proponowanych działaniach. Europejskie Towarzystwo Ekorozwoju zaprosiło do partnerstwa organizacje pozarządowe, uczelnie wyższe i przedsiębiorców. Z punktu widzenia działań edukacyjnych i proekologicznych taka inicjatywa jest idealnym rozwiązaniem, ponieważ służy promocji organizacji i instytucji działających na rzecz ochrony środowiska, wymianie kontaktów oraz ułatwia nawiązywanie współpracy przy realizacji wspólnych projektów na rzecz zrównoważonego rozwoju. Baza została stworzona w ramach projektu „Nasza Planeta - Mój Dom. Partnerstwo organizacji pozarządowych, środowisk akademickich i przedsiębiorców na rzecz zrównoważonego rozwoju - Zmiany Klimatu"s.

\section{Działalność organizacji NGO na przykładzie ekologicznego zagrożenia smogiem i walki $z$ nim}

W chwili obecnej to zanieczyszczenie powietrza jest postrzegane jako jeden $\mathrm{z}$ najważniejszych problemów środowiska $\mathrm{w}$ Polsce. Za najważniejsze powody tego typu zanieczyszczenia uznawane są emisja z dużych obiektów energetycznego spalania oraz emisja $\mathrm{z}$ transportu samochodowego. Polacy rzadziej zauważają wpływ emisji z indywidualnych źródeł na jakość powietrza, choć równocześnie prawie połowa Polaków uważa, że do poprawy stanu powietrza przyczyniłaby się wymiana starych pieców węglowych na piece nowocześniejsze. Podobna część badanych rozwiązania problemu jakości powietrza szukałaby w stosowaniu odnawialnych źródeł energii.

Świadomość istnienia smogu w społeczeństwie istnieje, natomiast kwestia zapobiegania temu niepokojącemu zjawisku wymaga jeszcze intensywnej, długoterminowej i nie jednorazowej akcji edukacyjnej. Niektóre organizacje podejmują już

\footnotetext{
${ }^{7}$ Zgodnie z Dyrektywą IPPC standard BAT służyć ma określaniu granicznych wielkości emisji dla większych zakładów przemysłowych w UE. Nie jest natomiast konieczne, aby określony był rodzaj urządzenia czy konkretna technologia. Celem jest raczej zaproponowanie limitów emisyjnych, które odzwierciedlają właściwe proporcje pomiędzy kosztami i korzyściami. Jednak przykład BREF-u dla przemysłu chloro-alkalicznego, wskazujący jako BAT metodę membranową, dowodzi, że Unia jest gotowa eliminować tą drogą konkretne technologie (w tym przypadku jest to zamiar wyeliminowania wykorzystywania rtęci). Na podstawie BAT określane są limity emisyjne, które muszą brać pod uwagę techniczną charakterystykę instalacji, jej lokalizację geograficzną i lokalne warunki środowiskowe. Wielkości limitów emisyjnych określane w pozwoleniu muszą dotyczyć tych zanieczyszczeń, które zakład będzie prawdopodobnie odprowadzał w znacznych ilościach, a w szczególności zanieczyszczeń priorytetowych wymienionych w Aneksie III do Dyrektywy (https://ippc.mos.gov.pl/ ippc/?id=33).

${ }^{8}$ Projekt współfinansowany ze środków Mechanizmu Finansowego Europejskiego Obszaru Gospodarczego oraz Norweskiego Mechanizmu Finansowego i budżetu RP, w ramach programu Funduszu dla Organizacji Pozarządowych (FOP), komponent II - Ochrona środowiska i zrównoważony rozwój.
} 
bardzo precyzyjne działania $\mathrm{w}$ tej dziedzinie. Wśród lokalnych organizacji zajmujących się z problematyką smogu prym wiodą stowarzyszenia i fundacje krakowskie. Wydaje się to oczywiste, biorąc pod uwagę, że ten ekologiczny problem od lat jest obecny w królewskim mieście, a jest to także drugie co do wielkości miasto w Polsce. Znaczenie dla rozwoju organizacji NGO oraz ich intensywnych działań ma z pewnością też poziom wykształcenia społeczności oraz jej wiek - społeczeństwa młodsze chętniej działają w trzecim sektorze. Poniżej przedstawiono wybrane organizacje działające w tym zakresie:

- Krakowski Alarm Smogowy - ruch społeczny, którego celem jest doprowadzenie jakości powietrza w Krakowie, w kilkuletniej perspektywie, do stanu zgodnego z prawem i bezpiecznego dla zdrowia mieszkańców (http://www.krakowskialarmsmogowy.pl/). Ruch przedstawia mieszkańcom ekspertyzy sporządzane na zalecenie Urzędu Marszałkowskiego Województwa Małopolskiego, by uświadomić im, że głównym źródłem smogu w Krakowie są indywidualne paleniska węglowe, czyli emisja powierzchniowa.

- Polski Alarm Smogowy - ogólnopolska sieć społecznego monitoringu powietrza, strona powstała dzięki współpracy organizacji i ruchów społecznych, skupiając informacje $\mathrm{z}$ całego kraju dotyczące smogu. Integruje w jednym portalu organizacje z całej Polski, jak „Krakowski Alarm Smogowy”.

- Stowarzyszenie Logiczna Alternatywa (Karkosza 2016) - krakowska organizacja NGO zarzucająca prezydentowi Krakowa, że problem smogu jest również jego zasługą, ponieważ pozwala on na zabudowę korytarzy przewietrzania miasta oraz na masową wycinkę zieleni w Krakowie.

- Nadchodzi Błękit - ruch obywatelski na rzecz czystego powietrza w Rybniku. Zachęcanie do komunikacji miejskiej, a nawet zmniejszenie ilości wypalanych papierosów. Ruch skupił wokół problemu bardzo zróżnicowane środowisko: urzędników, dziennikarzy, artystów i ludzi biznesu.

- Wolna Lubelszczyzna - stowarzyszenie, które zbiera podpisy pod apelem do władz miasta i województwa o wprowadzenie uchwały antysmogowej. Organizuje debaty i akcje uświadamiające mieszkańców.

Tego typu ruchy i działania prowadzone przez organizacje trzeciego sektora pojawiają się w każdym mieście wojewódzkim i w większości polskich gmin, które zmagają się ze zjawiskiem smogu. To dzięki ich aktywności, swoistej ekspansywności medialnej i działaniom na rzecz edukacji dzisiejsza świadomość społeczna na temat smogu jest znacznie wyższa niż jeszcze kilka lat temu.

Znaczenie proekologicznych organizacji pozarządowych w ochronie środowiska wzrasta w ostatnich latach. Zwiększyło się po wdrożeniu znowelizowanego prawa uwzględniającego dyrektywy unijne oraz postanowienia Konwencji z Aarhus (Konwencja o dostępie do informacji...), wyrażone w Ustawie z dnia 3 października 2008 r. o udostępnianiu informacji o środowisku i jego ochronie, udziale społeczeństwa $\mathrm{w}$ ochronie środowiska oraz o ocenie oddziaływania na środowisko (Dz.U. 2008 nr 199 poz. 1227). 


\section{Podsumowanie}

W artykule ukazano istotę działalności proekologicznej, która nie jest możliwa bez udziału organizacji pozarządowych. To właśnie organizacje, mając większą swobodę działania w niektórych obszarach (np.: mediów), z racji swej specyfiki będące bliżej istotnych problemów społecznych, przejmują zadania instytucji samorządowych i państwowych. Fundacje i stowarzyszenia nie mają możliwości nakładania podatków lub egzekwowania mandatów, stąd ich rola polega głównie na edukacji ekologicznej. Ze względu na sytuację socjologiczną, często polityczną i społeczną, głównymi odbiorcami wiedzy ekologicznej są obywatele w wieku średnim oraz dzieci i młodzież. W przypadku tych dwóch ostatnich grup i ich naturalnej niechęci do standardowej edukacji to właśnie trzeci sektor jest szansą na budowanie postaw świadomych ekologicznie konsumentów. Bez organizacji pozarządowych wiedza społeczeństwa dotycząca ekologii ograniczałaby się zapewnie do wysokości opłaty za wywóz śmieci i rachunków bieżących. Tymczasem swoista praca u podstaw licznych wolontariuszy i działaczy istotnie zmienia poziom świadomości, co bezpośrednio wpływa na widoczną zmianę postaw społecznych.

\section{Literatura}

1. Arystoteles (2002), Polityka, Altaya, Warszawa.

2. Barański M. (b.r.), Organizacje pozarzadowe $w$ społeczeństwie obywatelskim, http://www.ngo.us.edu.pl/skrypt/I.doc (dostęp: 05.05.2017).

3. Bugajski W. (2011), System pieniężny $i$ teoria pieniądza, Wyższa Szkoła Technik Komputerowych i Telekomunikacji w Kielcach, Kielce, http://www.wstkt.pl/materialy/ bugajski_03.pdf (dostęp: 06.05.2018).

4. CBOS (2000), BS/161/2000, Ekologiczna świadomość Polaków. Komunikat z badań, Centrum Badania Opinii Społecznej, Warszawa, listopad, http://www.cbos.pl/SPISKOM.POL/ 2000/K 161_00.PDF (dostęp: 06.05.2017).

5. Domański J. (2010), Zarzadzanie strategiczne organizacjami non-profit, Wolters Kluwer, Warszawa.

6. Dyrektywa Parlamentu Europejskiego i Rady 2008/1/WE z dnia 15 stycznia 2008 r. dotycząca zintegrowanego zapobiegania zanieczyszczeniom i ich kontroli (Dz. Urz. UE L 24/8, 29.1.2008)

7. Dyrektywa Parlamentu Europejskiego i Rady 2010/75/UE z dnia 24 listopada 2010 r. w sprawie emisji przemysłowych (zintegrowane zapobieganie zanieczyszczeniom i ich kontrola) (Dz. Urz. UE L 334/17, 17.12.2010).

8. http://sjp.pl/non+profit (dostęp: 04.05.2017).

9. http://www.krakowskialarmsmogowy.pl (dostęp: 10.05.2017).

10. https://ippc.mos.gov.pl/ippc/?id=33 (dostęp: 10.05.2017).

11. https://www.worldwildlife.org/ (dostęp: 06.05. 2017).

12. Karkosza M. (2016), Kraków. „Majchrowski, przestań truć!”. Marsz przeciw smogowi, Gazeta Krakowska, http://www.gazetakrakowska.pl/wiadomosci/krakow/a/krakow-majchrowski -przestan-truc-marsz-przeciw-smogowi,9486543/ (dostęp: 07.05.2017).

13. Konstytucja Rzeczypospolitej Polskiej z dnia 2 kwietnia 1997 r. uchwalona przez Zgromadzenie Narodowe w dniu 2 kwietnia 1997 r., przyjęta przez Naród w referendum konstytucyjnym w dniu 25 maja 1997 r., podpisana przez Prezydenta Rzeczypospolitej Polskiej w dniu 16 lipca 1997 r. (Dz.U. 1997 nr 78 poz. 483, z późn. zm.). 
14. Konwencja o dostępie do informacji, udziale społeczeństwa w podejmowaniu decyzji oraz dostępie do sprawiedliwości w sprawach dotyczących środowiska sporządzona w Aarhaus, dnia 25 czerwca 1998 r. (Dz.U. $2003 \mathrm{nr} 78$ poz. 706).

15. Kowałczewska J. (b.r.), Organizacje pozarządowe na rzecz zrównoważonego rozwoju - ich wspótpraca ze szkołami, RCCE Płock, http://www.rceeplock.nazwa.pl/files/rcee/mater_szkol/ 11_organizacje_pozarzadowe.pdf (dostęp: 05.05.2017).

16. Kwiatkowski E. (1982), Z problematyki genezy teorii trzech sektorów gospodarki, „Acta Universitatis Lodziensis. Folia Oeconomica”, nr 19, s. 11-28, http://dspace.uni.lodz.pl:8080/ xmlui/bitstream/handle/11089/6250/kwiatkowski11-28.pdf?sequence=1\&isAllowed=y (dostęp: 10.05.2017).

17. Łukasiak P., Stafiej-Bartosik A. (2006), Metoda K3 a planowanie strategii pozyskiwania funduszy, [w:] Wiedza i doświadczenie. Modut 4. Finanse $w$ organizacji pozarzadowej, Akademia Rozwoju Filantropii w Polsce, Warszawa, s. 11-21.

18. Sergeant A. (2004), Marketing w organizacjach non profit, Oficyna Ekonomiczna, Kraków.

19. TNS (2015), Badanie świadomości i zachowań ekologicznych mieszkańców w Polsce w latach 2009-2015, Raport TNS Polska dla Ministerstwa Środowiska, Warszawa.

20. Tyrakowski M. (2007), Rola organizacji pozarządowych $w$ rozwiązywaniu problemów społecznych, „Zeszyty Naukowe Zakładu Europeistyki Wyższej Szkoły Informatyki i Zarządzania w Rzeszowie", nr 2/(4), s. 172-196, http://znze.wsiz.rzeszow.pl/z04/9_Michal _Tyrakowski_Rola.pdf (dostęp: 06.05.2017).

21. Ustawa z dnia 13 września 1996 r. o utrzymaniu czystości i porządku w gminach (Dz.U. $1996 \mathrm{nr} 132$ poz. 622, z późn. zm.).

22. Ustawa $\mathrm{z}$ dnia 3 października 2008 r. o udostępnianiu informacji o środowisku i jego ochronie, udziale społeczeństwa w ochronie środowiska oraz o ocenach oddziaływania na środowisko (Dz.U. 2008 nr 199 poz. 1227, z późn. zm.).

23. Wydział Spraw Społecznych Urzędu Miasta Gorzowa Wlkp. (2015), Rozwiązywanie problemów pomocy spolecznej przez organizacje pozarządowe działajace na terenie miasta, Gorzów Wlkp., http://bip.wrota.lubuskie.pl/umgorzow/system/obj/5357_rozwiazywanie_ problemow_pomocy_spolecznej_KSS_2015.pdf (dostęp: 04.05.2017).

\title{
SHAPING THE SOCIAL ATTITUDE OF A CONSCIOUS CONSUMER OF FUELS AND ENERGY AS AN OBJECTIVE TO MANAGE PRO-ECOLOGICAL THIRD SECTOR
}

\begin{abstract}
The aim of the article is to show the need for ecological education conducted by institutions other than state and local government, originating from and being organic parts of civil society. The article also specifies the concept of third sector organizations and shows their role in shaping a conscious, pro-ecological social attitude. The issues of cooperation among all three sectors and their important role in sustainable development have also been discussed.
\end{abstract}

Keywords: smog alarm, CSR, environmental education, non-profit, NGOs, third sector, social movement, smog, permanent development, sustainable development 